\title{
Investigating Lecturer and Students' Perception on Mobile Learning Application (MLA) for Accounting Subjects in Indonesian Higher Education
}

\author{
Dhany Efita Sari, Noor Lela Ahmad, Anuar Sarun and Suyatmini
}

\section{ABSTRACT}

The objective of this research is to examine the perception of students and lecturers concerning the importance of the Mobile Learning Application (MLA) as a support for accounting learning activities. This is a survey research with a cross-sectional design that employs a questionnaire and is distributed to lecturers and students to determine their perceptions of MLA. Purposive sampling was used as a sampling technique. This study's samples included lecturers and students from three universities in Indonesia, Universitas Gunung Rinjani (representing eastern Indonesia), Universitas Muhammadiyah Sumatera Utara (representing western Indonesia), and Universitas Muhammadiyah Surakarta (representing the central part of Indonesia). The information gathered from the questionnaire was then analyzed descriptively. Based on the needs analysis findings, students and lecturers explained that the presence of MLA as a support for accounting learning activities is essential in order to improve learning quality and adapt to the changes of education in the era of society 5.0. They also want MLA to have learning outcomes, videos, sounds, and a colorful design. As a result, learning application developers should be able to produce applications that pay close attention to these aspects in order to support MLA and make it more appealing and in line with learning objectives.

Keywords: Mobile learning application, educational technology, accounting subject, higher education.

\section{INTRODUCTION}

According to UNESCO data, the closure of universities due to COVID-19 affected $1,198,530,172$ students in 186 countries around the world (UNESCO, 2020). Indonesian Ministry of Education and Culture (MOEC) and Indonesian Ministry of Religious Affairs (MORA) issued an Indonesian government response to the COVID-19 pandemic in May 2020. MOEC has designed Circular Letter 4/2020 to postpone all school programs and elect for online and distance learning at home.

Learning is currently carried out remotely and using digital platform methods [2]. Mobile learning is part of this digital platform methods. Mobile learning has become an integral part of the learning process during the Covid-19 pandemic, because mobile devices such as smartphones, tablets and laptops are the main telecommunications tools for online learning [3].

The use of smartphones in learning is appropriate by higher education policies. Many students already have their own smartphones [4], and they are widely used in formal and informal classes for learning [5]. Previous smartphones have and high schools.
Published Online: October 12, 2021

ISSN: $2736-4534$

DOI : 10.24018/ejedu.2021.2.5.157

D. E. Sari *

Universiti Pendidikan Sultan Idris,

Malaysia.

(e-mail: des576@ums.ac.id)

N. L. Ahmad

Universiti Pendidikan Sultan Idris,

Malaysia.

(e-mail: noor.lela@fpe.upsi.edu.my)

A. Sarun

Universiti Pendidikan Sultan Idris,

Malaysia.

(e-mail: anuar.sarun@fpe.upsi.edu.my) Suyatmini

Universitas Muhammadiyah Surakarta, Indonesia.

(e-mail: suy276@ums.ac.id)

*Corresponding Author

been extensively used and researched in other countries [6][8] before growing the number of smartphone users in Indonesia. Indonesia, as the world's fourth-largest smartphone user, has a rare ability to use smartphones as mobile technology in education and learning [9].

Mobile education offers many opportunities in Indonesia to improve the standard of education. The penetration of mobile technology is rapid and is continuing to increase in Indonesia. Moreover, new findings and application experience from international and local researchers in other countries could support mobile learning in Indonesia. In addition, number of supports have been developed by MOEC for easy online learning. They develop android-based distance learning applications called "Rumah Belajar" [10]. This portal could be accessed on http://learning.kemdikbud.go.id. Students and teachers could connect with the great features on it. It can be utilized by students and teachers in early childhood, primary, secondary,

In line with the higher education context, universities have also used LMS, online conference platforms and the mobile learning application (MLA) as a learning tool [11]. In the case 
of Indonesian higher education institutions, the option of MLA is inevitable throughout COVID-19 [12]. MLA is one of the learning resources that can be used in higher education in Indonesia.

However, MLA is still rarely used for accounting education in Indonesia. As a result, this research makes a scientific contribution to the field of accounting education, especially in the area of adjusting entries learning material. Many students in Indonesia also have trouble understanding it, which has become a source of concern for accounting teachers [13], [14]. As a result, there is a lack of information about the foundation for filing financial statements, which should be mastered by undergraduate students who are preparing to serve as financial workers in companies and government departments.your paper.

\section{Mobile LeARning ApPlicAtion (MLA)}

In response to educational problems at the age of the industrial revolution 4.0, society 5.0, smartphones are permitted in universities. As a result, several institutions have begun to use MLA on cellphones as teaching resources and learning media [4], [5].

The MLA is according to Handal \& El-khoury [15] "a kind of learning activity which is linked to the application, a learning experience supported by the application and its media, and can promote cognitive engagement and management of student learning through this application" ( $\mathrm{p}$. 144). Camilleri \& Camilleri [16] further notes that MLA is a learning application.

Bloom's taxonomy MLA is classified into three categories: MLA based on skills, content and function based [17] Table I below describes the definitions of the three mobile learning apps.

TABLE I: TYPES OF MLA BASED ON BLOOM'S TAXONOMY

\begin{tabular}{|c|c|c|c|}
\hline Category & Skill-based & Content-based & $\begin{array}{c}\text { Function- } \\
\text { based }\end{array}$ \\
\hline Description & $\begin{array}{c}\text { Used for } \\
\text { memorization, } \\
\text { memorization, } \\
\text { numeracy skills, } \\
\text { standardized } \\
\text { test readiness, } \\
\text { and areas of } \\
\text { knowledge. }\end{array}$ & $\begin{array}{l}\text { Give students } \\
\text { access to a } \\
\text { number of data, } \\
\text { information or } \\
\text { knowledge by } \\
\text { browsing pre- } \\
\text { programmed } \\
\text { content. }\end{array}$ & $\begin{array}{c}\text { Assist } \\
\text { students in } \\
\text { converting } \\
\text { knowledge } \\
\text { information } \\
\text { into a usable } \\
\text { form. }\end{array}$ \\
\hline $\begin{array}{c}\text { Implications of } \\
\text { Bloom's } \\
\text { Taxon-omy } \\
\end{array}$ & $\begin{array}{c}\text { Level of } \\
\text { knowledge and } \\
\text { understanding. }\end{array}$ & $\begin{array}{l}\text { Application } \\
\text { level and } \\
\text { analysis. }\end{array}$ & $\begin{array}{c}\text { Evaluation } \\
\text { and creation } \\
\text { level. }\end{array}$ \\
\hline
\end{tabular}

The MLA to be developed is separated into two groups based on the three categories in Table I. MLA is divided into two categories: skill-based MLA and content-based MLA. A skill-based program designed to increase pupils' memory and comprehension abilities. Furthermore, content-based apps are utilized to help students develop their abilities in applying and interpreting journal information. The two types of applications will be merged into a single MLA with the content of the Service Company Accounting course's adjusting journal material.

\section{Methodology}

\section{A. Research Goal}

This survey study aimed to gather student and lecturer perceptions of the Mobile Learning Application (MLA) required for accounting learning. As a result, a cross-sectional survey design was used to assess the need for this MLA.

\section{B. Sample and Data Collection}

Because data was collected only once at a specific time, this study employed a cross-sectional survey research design [18]. Purposive sampling is used in the data collection technique because the samples taken require particular criteria that are tailored to the study's objectives [18]. As a result, the samples for this study were lecturers and students from various universities, including Universitas Gunung Rinjani (representing eastern Indonesia), Universitas Muhammadiyah Sumatera Utara (representing western Indonesia), and Universitas Muhammadiyah Surakarta (representing the central part of Indonesia). The sample was chosen because the samples were homogeneous when viewed from the perspective of the same institution's accreditation.

\section{Data Collection Instruments}

The instruments for data collection were two types of questionnaires: one to assess lecturers' perceptions of MLA and another to assess students' perceptions of MLA. The items in the instrument that we use are as follows on Table II.

TABLE II: GRID OF RESEARCH INSTRUMENTS

\begin{tabular}{|c|c|c|}
\hline Instruments & Part of instruments & $\begin{array}{l}\text { The number of } \\
\text { instrument items }\end{array}$ \\
\hline $\begin{array}{l}\text { Need Analysis } \\
\text { Questionnaire for } \\
\text { Lecturers (code: } \\
\text { NAQ. L) }\end{array}$ & $\begin{array}{l}\text { 1. Part 1: strength of MLA } \\
\text { in teaching. } \\
\text { 2. Part 2: attitudes towards } \\
\text { MLA in teaching. } \\
\text { 3. Part 3: special } \\
\text { requirement about MLA } \\
\text { (close ended question). }\end{array}$ & $\begin{array}{l}\text { 1. Part 1: } 17 \text { items } \\
\text { 2. Part 2: } 3 \text { items } \\
\text { 3. Part 3: } 5 \text { items }\end{array}$ \\
\hline $\begin{array}{c}\text { Need Analysis } \\
\text { Questionnaire for } \\
\text { Students (code: } \\
\text { NAQ.S) }\end{array}$ & $\begin{array}{c}\text { 1. Part 1: student } \\
\text { perception on mobile } \\
\text { learning application (MLA) } \\
\text { in Learning } \\
\text { 2. Part 2: student's } \\
\text { requirements regarding to } \\
\text { MLA. }\end{array}$ & $\begin{array}{l}\text { 1. Part 1: } 10 \text { items } \\
\text { 2. Part 2: } 5 \text { items }\end{array}$ \\
\hline
\end{tabular}

\section{Data Collection}

Data was collected through the use of two types of questionnaires distributed to students and lecturers. Lecturers were given a questionnaire with the code NAQ.L, whereas students were given a questionnaire with the code NAQ.S. NAQ.L and NAQ.S are distributed via a Google form (webbased questionnaire) because it is associated with the COVID-19 pandemic. NAQ.L was given to two Universitas Gunung Rinjani (UGR) lecturers, two Universitas Muhammadiyah Sumatera Utara (UMSU) lecturers, and a lecturer from Universitas Muhammadiyah Surakarta (UMS). The NAQ.S was then distributed to twenty students from Universitas Gunung Rinjani (UGR), twenty students from Universitas Muhammadiyah Sumatera Utara (UMSU), and twenty students from Universitas Muhammadiyah Surakarta (UMS). 


\section{E. Data Analysis}

The data from NAQ.L and NAQ.S were analyzed descriptively using SPSS in this study.

\section{RESUlt AND Discussion}

\section{A. Result}

Table III shows the results of the descriptive statistical analysis performed in SPSS. The study's findings came from two research subjects, students and lecturers.

TABLE III: DESCRIPTIVE STATISTIC FOR NEED ANALYSIS QUESTIONNAIRE FOR STUDENTS (NAQ.S)

\begin{tabular}{|c|c|c|c|}
\hline $\begin{array}{c}\text { Number of } \\
\text { instrument } \\
\text { items }\end{array}$ & $\begin{array}{c}\text { Student Perception on Mobile } \\
\text { Learning Application (MLA) in } \\
\text { Learning } \\
\end{array}$ & $\overline{\mathrm{x}}$ & SD \\
\hline \multicolumn{4}{|c|}{$\begin{array}{c}\text { PART I } \\
\end{array}$} \\
\hline $\begin{array}{c}\text { NAQ. S } \\
\text { Part 1, } \\
\text { Question } 1\end{array}$ & $\begin{array}{l}\text { The use of mobile learning aps is } \\
\text { convenient and allows a flexible } \\
\text { learning. }\end{array}$ & 4.34 & 0.545 \\
\hline $\begin{array}{l}\text { NAQ. S } \\
\text { Part 1, } \\
\text { Question } 2\end{array}$ & $\begin{array}{l}\text { The use of mobile learning app } \\
\text { enables lecturers to take control } \\
\text { of learning. }\end{array}$ & 4.25 & 0.762 \\
\hline $\begin{array}{l}\text { NAQ. S } \\
\text { Part 1, } \\
\text { Question } 3\end{array}$ & It is good use of "dead time". & 4.50 & 0.508 \\
\hline $\begin{array}{l}\text { NAQ. S } \\
\text { Part 1, } \\
\text { Question } 4\end{array}$ & $\begin{array}{l}\text { It fits for many different learning } \\
\text { styles. }\end{array}$ & 3.97 & 0.933 \\
\hline $\begin{array}{l}\text { NAQ. S } \\
\text { Part 1, } \\
\text { Question } 5\end{array}$ & $\begin{array}{l}\text { It improves my self-confidence } \\
\text { in learning throughout mobile } \\
\text { connection activities. }\end{array}$ & 4.28 & 0.523 \\
\hline $\begin{array}{l}\text { NAQ.S } \\
\text { Part 1, } \\
\text { Question } 6\end{array}$ & $\begin{array}{l}\text { It improves my self- confidence } \\
\text { in learning throughout mobile } \\
\text { communication activities. }\end{array}$ & 4.22 & 0.491 \\
\hline $\begin{array}{l}\text { NAQ.S } \\
\text { Part 1, } \\
\text { Question } 7\end{array}$ & $\begin{array}{l}\text { It improves my self-confidence } \\
\text { in learning throughout mobile } \\
\text { collaboration. }\end{array}$ & 4.19 & 0.044 \\
\hline $\begin{array}{c}\text { NAQ.S } \\
\text { Part 1, } \\
\text { Question } 8\end{array}$ & $\begin{array}{l}\text { It improves my engagement in } \\
\text { mobile connection activities. }\end{array}$ & 4.28 & 0.581 \\
\hline $\begin{array}{c}\text { NAQ.S, } \\
\text { Part 1, } \\
\text { Question } 9\end{array}$ & $\begin{array}{l}\text { It improves my engagement in } \\
\text { mobile communication activities. }\end{array}$ & 4.25 & 0.622 \\
\hline $\begin{array}{c}\text { NAQ. S } \\
\text { Part } 1 \\
\text { Question } 10\end{array}$ & $\begin{array}{l}\text { It improves my engagement in } \\
\text { mobile collaboration. }\end{array}$ & 4.22 & 0.608 \\
\hline \multicolumn{4}{|c|}{ PART II } \\
\hline $\begin{array}{c}\text { NAQ. S } \\
\text { Part 2, } \\
\text { Question 1 }\end{array}$ & $\begin{array}{l}\text { Do you have a smartphone } \\
\text { (Android or iOS)? }\end{array}$ & 1.00 & 0.000 \\
\hline $\begin{array}{c}\text { NAQ. S } \\
\text { Part 2, } \\
\text { Question 2 }\end{array}$ & $\begin{array}{l}\text { Is MLA in your smartphone } \\
\text { would be effective applied in } \\
\text { accounting education? }\end{array}$ & 0.81 & 0.397 \\
\hline $\begin{array}{l}\text { NAQ. S } \\
\text { Part 2, } \\
\text { Question } 3\end{array}$ & $\begin{array}{l}\text { What are the kinds of MLA } \\
\text { features do you need? (Select } \\
\text { more than one of all aspects as } \\
\text { your requirements) }\end{array}$ & & \\
\hline $\begin{array}{l}\text { NAQ. S } \\
\text { Part 2, } \\
\text { Question } 4\end{array}$ & $\begin{array}{l}\text { Do you like moving animations } \\
\text { on the MLA? }\end{array}$ & 0.97 & 0.177 \\
\hline $\begin{array}{c}\text { NAQ. S } \\
\text { Part 2, } \\
\text { Question } 5\end{array}$ & $\begin{array}{l}\text { For evaluation, is game- } \\
\text { embedded assessment is a best } \\
\text { way for MLA? }\end{array}$ & 0.88 & 0.336 \\
\hline
\end{tabular}

\section{B. Need Analysis for Students}

The study's findings are based on the NAQ instrument, as shown in Table III. For NAQ, L Part 1 is the Student Perception on Mobile Learning Application (MLA) aspect. S Since Question 1 has an average score of 4.34 , which is higher than 3.00, it can be concluded that using MLA would make learning more accessible and enjoyable for students. Question 2 of the NAQ.S has an average score of 4.25 , indicating that the score is higher than 3.00, indicating that the presence of MLA would enable lecturers to monitor learning activities, according to students. NAQ. S Question 3 has an average score of 4.50 , which is higher than 3.00, indicating that all students agree that MLA should be used in an urgent situation.

Furthermore, the research findings based on the NAQ.S Question 4 instrument have an average score of 3.97, which is higher than 3.00, and only a few students agree that MLA can be used by all students with various learning styles. NAQ.S Question 5 has an average score of 4.28, meaning that the score is above 3.00 with the assumption that MLA can increase the confidence of each student in learning through cellular-based connection activities. NAQ.S Question 6 has an average score of 4.22 , meaning that the score is above 3.00 so that students agree with the perception that using MLA will increase students' confidence in learning by implication of cellular communication activities.

NAQ.S Question 7 has an average score of 4.19, which means it is higher than 3.00. Students agree with the perception that using MLA can boost students' selfconfidence in learning through cellular-based collaborative activities. NAQ.S Question 8 has an average score of 4.28, which is higher than 3.00 if students believe that using MLA will increase student involvement in cellular-based connection activities. The average score for NAQ. S Question 9 is 4.25; a score higher than 3.00 indicates that students agree with the perception that MLA will increase student involvement in cellular-based communication. NAQ.S Question 10 has an average score of 4.22, which is larger than 3.00 , indicating that students agree with the perception that MLA can increase student participation in mobile-based collaboration.

The study's findings are based on the NAQ instrument, as shown in Table III. S Part 2, student requirements for MLA, on NAQ.S Question 1, yielded 100 percent results (fig. 1.), implying that all students have smartphones (Android or iOS), allowing users to easily access MLA. MLA can be used to support classroom activities because all students have smartphones. It will be easier to integrate learning activities through MLA if each student owns a smartphone because they already have the media to access MLA.

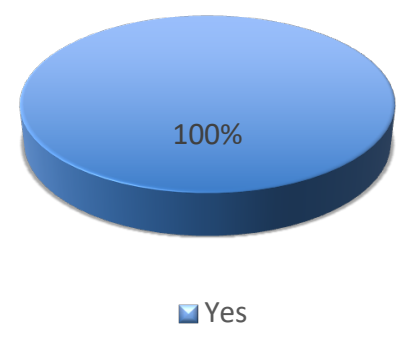

Fig. 1. For students who own a smartphone.

Note: $\mathrm{n}=60$ number of student responses. Likert-type ratings (1-5) are percentages of students responding in each of the two parts in the NAQ.S.

NAQ.S Question 2, the results show that approximately $81.3 \%$ believe MLA is effective when used in accounting education, even as roughly 18.8 percent believe MLA is 
inadequate when used in accounting education. According Fig. 2. students believe that MLA is useful when used in accounting learning 81.3 percent of the time, whereas 18.8 percent believe that MLA is less effective when used in accounting learning since there are various explanations that cannot be stated in accounting. Students can understand without the lecturer's help.

NAQ.S Question 2, the results show that approximately $81.3 \%$ believe MLA is effective when used in accounting education, even as roughly 18.8 percent believe MLA is inadequate when used in accounting education. According Fig. 2. students believe that MLA is useful when used in accounting learning 81.3 percent of the time, whereas 18.8 percent believe that MLA is less effective when used in accounting learning since there are various explanations that cannot be stated in accounting. Students can understand without the lecturer's help.

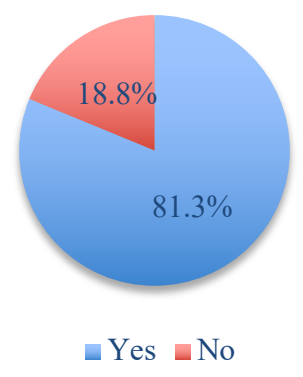

Fig. 2. Effectiveness of MLA for students.

Note: $\mathrm{n}=60$ number of student responses. Likert-type ratings (1-5) are percentages of students responding in each of the two parts in the NAQ.S.

NAQ.S Question 3, in this section, there are several MLA features required by students, with features in the form of videos receiving the highest polling of 84.4 percent, reflecting that students truly require features in the form of videos in MLA. Moreover, other MLA features required by students in the form of sounds and learning outcomes on apps yielded $75 \%$ results, The needs of students for MLA features such as Android and iOS compatibility are approximately 65.6 percent. Furthermore, students require the MLA feature in the form of a colorful design at around 53.1 percent, while students require the MLA feature in the form of more illustrations at around fifty percent. Meanwhile, another MLA feature in the form of navigation apps is required by approximately 34.4 percent of students, while another MLA feature, more text, is required by approximately 15.6 percent of students. Based on Fig. 3. Students need more videos feature in MLA, it's combination of audio and visual, making students feel interested. The video component in MLA will make it easier for students to understand accounting information if it is coupled with accounting learning.

According to the results of NAQ.S, Question 4, approximately 96.9 percent of students like moving animation in MLA, while approximately 3.1 percent of students do not like moving animation. According Fig. 4. shows students prefer MLA when it includes moving animation, and they regard moving animation as a valuable addition to MLA. As a result, students will not be bored while they are studying. However, some students dislike moving animation since they believe it is unnecessary in MLA because it will cause them to lose attention on the learning material if it is present.

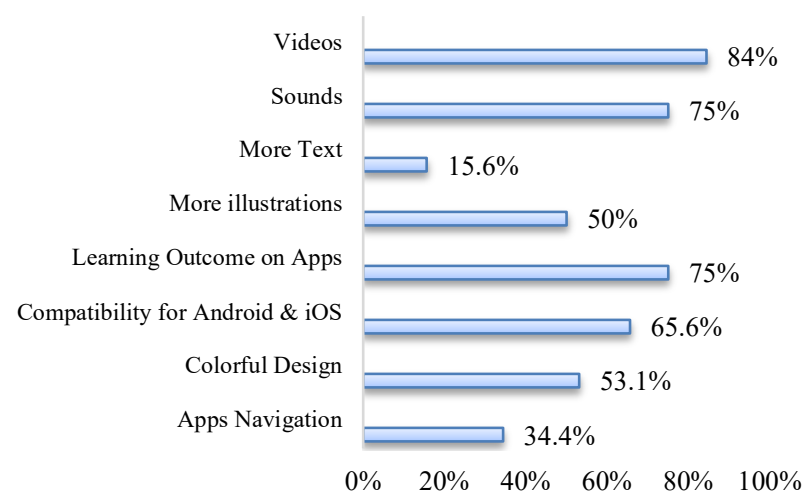

Fig. 3. MLA requirement based on students' perception. Note: $\mathrm{n}=60$ number of student responses. Likert-type ratings (1-5) are percentages of students responding in each of the two parts in the NAQ.S.

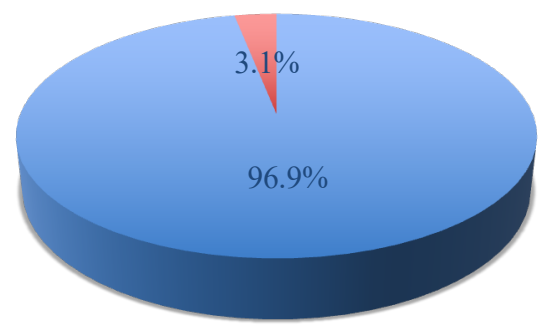

$$
\text { Yes No }
$$

Fig. 4. MLA animation for students.

Note: $\mathrm{n}=60$ number of student responses. Likert-type ratings (1-5) are percentages of students responding in each of the two parts in the NAQ.S.

Furthermore, the results of NAQ.S, Question 5, revealed that approximately 87.5 percent of students thought that game integrated in MLA for assessment is the best way to evaluate learning, contrary, 12.5 percent of students thought that this is not the best way to evaluate learning. Based on Fig. 5. It shows that some students agree that in MLA, there is an evaluation in the form of a game that is used as material for taking accounting marks, which is an exciting thing for students. However, some argue that the evaluation in the form of a game, which is connected with MLA, should be used as a value-taking material in accounting classes.

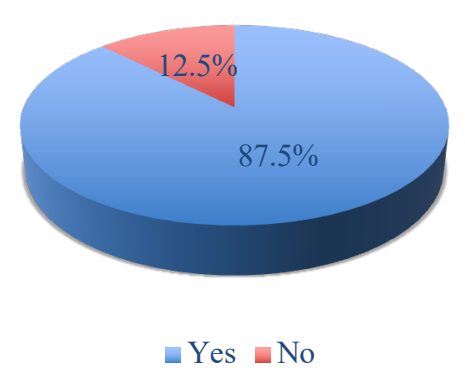

Fig. 5. Game-embedded assessment on MLA for students. Note: $\mathrm{n}=60$ number of student responses. Likert-type ratings (1-5) are percentages of students responding in each of the two parts in the NAQ.S. 
TABLE IV: DESCRIPTIVE STATISTIC FOR NEED ANALYSIS QUESTIONNAIRE FOR LECTURERS (NAQ.L)

\begin{tabular}{|c|c|c|c|}
\hline $\begin{array}{l}\text { Number of } \\
\text { instrument items }\end{array}$ & Strength of MLA in teaching & $\overline{\mathrm{x}}$ & SD \\
\hline \multicolumn{4}{|c|}{ PART 1} \\
\hline $\begin{array}{l}\text { NAQ.L Part 1, } \\
\text { Question } 1\end{array}$ & $\begin{array}{l}\text { It will enable students to have access to learning } \\
\text { material fast and easily. }\end{array}$ & 4.00 & 0.707 \\
\hline $\begin{array}{l}\text { NAQ.L Part 1, } \\
\text { Question } 2\end{array}$ & $\begin{array}{c}\text { Mobile learning supports individual learning } \\
\text { opportunities. }\end{array}$ & 4.20 & 0.447 \\
\hline $\begin{array}{l}\text { NAQ.L Part } 1 \\
\text { Question } 3\end{array}$ & $\begin{array}{c}\text { Mobile learning motivates learners when used for } \\
\text { learning. }\end{array}$ & 4.20 & 0.447 \\
\hline $\begin{array}{l}\text { NAQ. L Part 1, } \\
\text { Question } 4\end{array}$ & It will promote lifelong learning opportunities. & 4.00 & 0.707 \\
\hline $\begin{array}{l}\text { NAQ. L Part 1, } \\
\text { Question } 5\end{array}$ & It will make learning interesting and enjoyable. & 3.80 & 0.447 \\
\hline $\begin{array}{l}\text { NAQ. L Part 1, } \\
\text { Question } 6\end{array}$ & It enables students to learn anywhere. & 4.40 & 0.548 \\
\hline $\begin{array}{l}\text { NAQ. L Part 1, } \\
\text { Question } 7\end{array}$ & It encourages learners to become inquisitive. & 4.00 & 0.707 \\
\hline $\begin{array}{l}\text { NAQ. L Part 1, } \\
\text { Question } 8\end{array}$ & It enables learners to learn more efficiently. & 4.20 & 0.447 \\
\hline $\begin{array}{l}\text { NAQ. L Part 1, } \\
\text { Question } 9\end{array}$ & Its portability offers comfort and ease to learners. & 3.40 & 0.894 \\
\hline $\begin{array}{l}\text { NAQ. L Part 1, } \\
\text { Question } 10\end{array}$ & It improves student learning outcome. & 3.80 & 0.837 \\
\hline $\begin{array}{l}\text { NAQ. L Part 1, } \\
\text { Question } 11\end{array}$ & It enables to learn by using apps in their spare time. & 4.20 & 0.447 \\
\hline $\begin{array}{l}\text { NAQ. L Part 1, } \\
\text { Question } 12\end{array}$ & It enables students to learn anytime. & 4.20 & 0.447 \\
\hline $\begin{array}{l}\text { NAQ. L Part 1, } \\
\text { Question } 13\end{array}$ & It enables learners more once in learning process. & 3.80 & 0.837 \\
\hline $\begin{array}{l}\text { NAQ. L Part 1, } \\
\text { Question } 14\end{array}$ & It provides equal opportunities for students to learn. & 4.00 & 0.707 \\
\hline $\begin{array}{l}\text { NAQ. L Part 1, } \\
\text { Question } 15\end{array}$ & $\begin{array}{l}\text { It supports learning by enhancing learner-learner } \\
\text { interaction. }\end{array}$ & 3.60 & 1.140 \\
\hline $\begin{array}{l}\text { NAQ. L Part 1, } \\
\text { Question } 16\end{array}$ & $\begin{array}{l}\text { It supports learning by enhancing teacher-learner } \\
\text { interaction. }\end{array}$ & 3.60 & 0.548 \\
\hline $\begin{array}{l}\text { NAQ. L Part 1, } \\
\text { Question } 17\end{array}$ & It once learners concentrate on lessons better. & 3.80 & 0.837 \\
\hline \multicolumn{4}{|c|}{ PART 2 } \\
\hline $\begin{array}{l}\text { NAQ. L Part 2, } \\
\text { Question } 1\end{array}$ & $\begin{array}{l}\text { I will use it as learning tool and also learning material } \\
\text { in my lessons. }\end{array}$ & 4.00 & 0.707 \\
\hline $\begin{array}{l}\text { NAQ. L Part 2, } \\
\text { Question } 2\end{array}$ & I think it should be commonly used in education. & 3.40 & 0.894 \\
\hline $\begin{array}{l}\text { NAQ. L Part 2, } \\
\text { Question } 3\end{array}$ & I think it must be used in every lesson at every stage. & 3.40 & 1.140 \\
\hline \multicolumn{4}{|c|}{ PART 3} \\
\hline $\begin{array}{l}\text { NAQ. L Part 3, } \\
\text { Question } 1\end{array}$ & Do you have a smartphone (Android or iOS)? & 1.00 & 0.000 \\
\hline $\begin{array}{l}\text { NAQ. L Part 3, } \\
\text { Question } 2\end{array}$ & $\begin{array}{l}\text { Is MLA in your smartphone would be effective } \\
\text { applied in accounting education? }\end{array}$ & 1.00 & 0.000 \\
\hline $\begin{array}{l}\text { NAQ. L Part 3, } \\
\text { Question } 3\end{array}$ & $\begin{array}{c}\text { What are the kinds of MLA features do you need? } \\
\text { (Select more than one of all aspects as your } \\
\text { requirements) }\end{array}$ & & \\
\hline $\begin{array}{l}\text { NAQ. L Part 3, } \\
\text { Question } 4\end{array}$ & Do you like moving animations on the MLA? & 0.80 & 0.447 \\
\hline $\begin{array}{l}\text { NAQ. L Part 3, } \\
\text { Question } 5\end{array}$ & $\begin{array}{c}\text { For evaluation, is game-embedded assessment is a } \\
\text { best way for MLA? }\end{array}$ & 1.00 & 0.000 \\
\hline
\end{tabular}

Note: $\mathrm{n}=5$ number of lecturer responses. Likert-type ratings (1-5) are percentages of lecturers responding in each of the three parts in the NAQ.L; $\overline{\mathrm{x}}$, Mean; $\mathrm{SD}$, Standard deviation.

\section{Need Analysis for Lecturers}

According to Table IV, Part 1, the strength of MLA in teaching, with a mean score above 3.00 , lecturers believe that if MLA is used in the classroom, the learning process will be more effective. The existence of MLA, according to all lecturers, would enable students to study anywhere; this has been supported by NAQ.L Question 6, which had an average score of 4.40. MLA, according to the lecturer, supports individual learning opportunities, motivates students to learn, empowers students to study more efficiently, encourages students to study in their free time, and facilitates students to study at any time. Only a few lecturers thought MLA provided comfort and convenience for students, as evidenced by an average score of 3.40 , despite the fact that the score was higher than 3.00 but the item's score was rated the lowest among the scores of other items.

According to Table IV, Part 2, attitudes toward MLA in teaching, all lecturers will use MLA as a learning tool and learning material during the teaching process. This is evident in NAQ.L Question 1 with a score of 4.00 on average. In contrast, NAQ.L Questions 2 and 3 have an average score of 3.40 , indicating that only a few lecturers believe that MLA should be used broadly in education and at all stages of learning.

According to Table IV, Part 3, lecturer's MLA requirements, the results of NAQ.L Question 1 show that the lecturer owns a smartphone 100 percent of the time (Fig. 6.), implying that all lecturers can easily access MLA via a smartphone. That all lecturers already have smartphones, this 
is a good start for implementing MLA in learning activities. If every lecturer has a smartphone, then they can monitor student progress, anywhere and anytime.

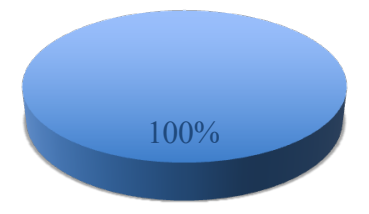

\section{- All lecturers have smartphone}

Fig. 6. For lecturers who own a smartphone.

Note: $\mathrm{n}=5$ number of lecturer responses. Likert-type ratings (1-5) are percentages of lecturers responding in each of the three parts in the NAQ.L.

NAQ.L Question 2, the effectiveness of using MLA for accounting learning activities according to the lecturer shows a result of $100 \%$, indicating on Fig. 7. that accounting learning activities for lecturers will run smoothly if supported by MLA. The use of MLA in accounting learning activities can make it easier for lecturers to give students with material. In order for students to have easy access to the content, this is very beneficial in terms of time, because the lecturer can deliver material connected to accounting at any time.

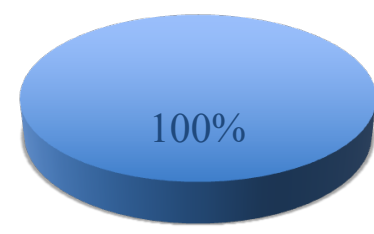

It will be effective

Fig. 7. Effectiveness of MLA for lecturers

Note: $\mathrm{n}=5$ number of lecturer responses. Likert-type ratings (1-5) are percentages of lecturers responding in each of the three parts in the NAQ.L.

NAQ.L Question 3 in this section, there are several MLA features needed for lecturers, learning outcomes on apps and sounds have the highest poll, the result is $80 \%$, it can be said that the learning outcomes on apps and sounds feature is really needed by lecturers in MLA. Even so, the result for features in the form of videos is $60 \%$, indicating that the lecturer believes these features are required in MLA to make it easier to deliver accounting learning material. The lecturer believes that a feature in the form of a colorful design is needed in MLA so that accounting learning activities will be more interesting if the design in MLA is made more colorful. For instance, with a result of $20 \%$ for features such as more illustrations, compatibility for Android \& iOS, and navigation apps, it can be stated that these features occupy the least number of polls, implying that these features for lecturers are not really needed in MLA. According to Fig. 8., lecturers want voice features and learning outcomes on apps to enhance accounting learning activities.

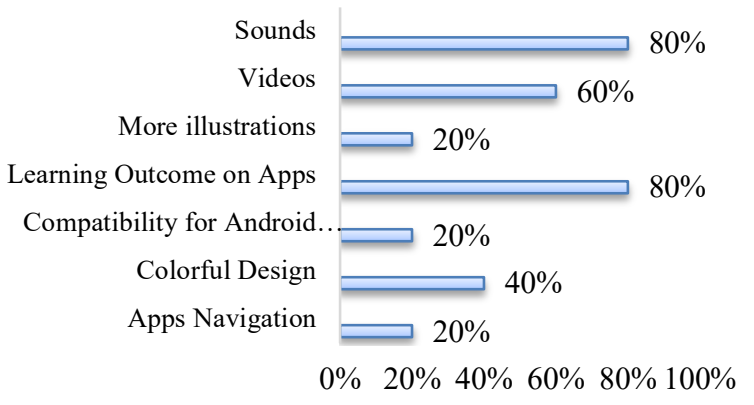

Fig. 8. Need analysis features MLA for lecturers.

Note: $\mathrm{n}=5$ number of lecturer responses. Likert-type ratings $(1-5)$ are percentages of lecturers responding in each of the three parts in the NAQ.L.

NAQ.L Question 4, based on Fig. 9. approximately $80 \%$ of lecturers prefer moving animation in MLA, while approximately $20 \%$ do not. Based on Fig. 9. shows that almost all lecturers feel that MLA should include moving animation to make the MLA display more attractive and varied. However, some lecturers disagree with the inclusion of moving animation in MLA since it is deemed disturbing if the animation moves too much.

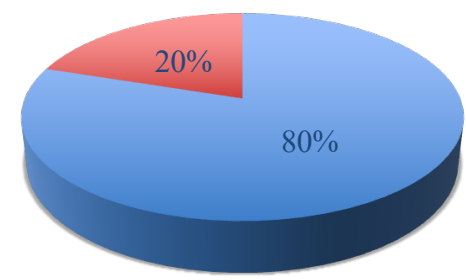

- Yes $\square$ No

Fig. 9. Moving animations on MLA for lecturers.

Note: $\mathrm{n}=5$ number of lecturer responses. Likert-type ratings (1-5) are percentages of lecturers responding in each of the three parts in the NAQ.L.

NAQ.L Question 5, based on Fig. 10. it shows 100 percent of lecturers thought that assessment in the form of a game integrated with MLA was the best way to evaluate learning. According to the Fig. 10, all lecturers agree that learning evaluation should be in the form of MLA-integrated games. Because MLA-style practice questions will make it easier for lecturers to assess students' knowledge of the content.

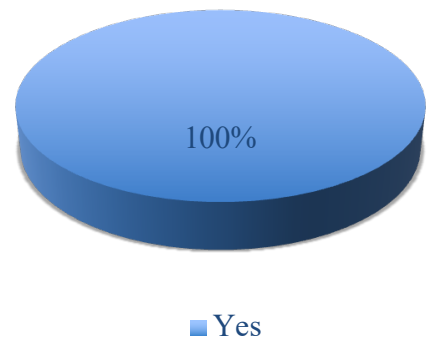

Fig. 10. Game-embedded assessment on MLA for lecturers.

Note: $\mathrm{n}=5$ number of lecturer responses. Likert-type ratings (1-5) are percentages of lecturers responding in each of the three parts in the NAQ.L.

\section{Discussion}

Based on an analysis of the needs of students and lecturers, the existence of MLA as a support for accounting learning 
activities is deemed necessary in order to improve learning quality and respond to the challenges of education in the society era 5.0. The analysis of the data in this study revealed an average score of more than 3 on "the use of MLA for students," indicating that students believe MLA is important to support accounting learning activities. Since smartphones will provide more benefits as a learning support tool in educational settings [19], [20]. Students value it, and the existence of MLA is due to the ease and flexibility with which it can be utilized.

In line with research conducted by Yang [21], students emphasize their positive attitude and ability to use smartphones with ease. Students believe that MLA will increase student engagement. Student engagement in online learning is frequently associated with improved learning outcomes; this is supported by the use of online learning through a platform that has a positive relationship between student involvement and online learning resources and enhanced learning outcomes [22]. Thus, student involvement has a positive effect and is thought to be important for students' academic ability, achievement, welfare, and socialization in order for them to learn effectively [23]-[25].

Moreover, students believe that evaluating learning in the form of games that are integrated with MLA is important. Several indicators will be used to assess student involvement in online learning, active student learning online, online academic relevance, online teaching, online collaboration, and online social interaction [26]. A study conducted by Agustina \& Wahyudi [27] clearly shows that learning applications with game features as a learning evaluation will make it easier for students of all ages to be applied in the learning process. Students' analysis of MLA to support learning activities, equipped with colorful designs, sounds, video illustrations, and learning outcomes, based on the results of this study. Students will be drawn to participate in learning activities if there is a suitable learning platform [28].

The findings of this study examined not only the needs of students, but also those of lecturers. Because MLA is designed as a development of problem-based learning methods, the emphasis in this method is through critical thinking and social interaction in small groups to solve problems, the lecturer believes that its existence will increase interaction between students with one another during online learning [29]. MLA's presence as an accounting learning tool will encourage students to engage in learning activities. The use of information and communication technology in accounting education will improve student learning outcomes and motivate students to learn [30]. MLA, according to the lecturer, will also provide enjoyable learning. According to research conducted by Farrely and Hudson [31], the use of information technology by lecturers in introductory accounting will provide a pleasurable learning time.

\section{CONCLUSION}

The purpose of this research is to investigate the needs of students and lecturers regarding the importance of MLA as a support for accounting learning activities. As a result, the existence of MLA will provide students with comfort in their learning because they believe that using MLA is more adaptable. Furthermore, the lecturer claims that the existence of MLA will increase students' motivation to learn and will provide individual learning opportunities due to the quick and easy access to material.

Students and lecturers require MLA to support learning activities because it is equipped with a variety of features such as learning outcomes on app, videos, sounds, and colorful designs. As a result, this feature will make it easier for students to access the material. For instance, lecturers want MLA to be simple to use in learning activities.

\section{ACKNOWLEDGEMENT}

Author thanks to Universiti Pendidikan Sultan Idris, Malaysia and Universitas Muhammadiyah Surakarta, Indonesia for supporting us to join for this publication.

\section{REFERENCES}

[1] UNESCO, Policy guidelines for mobile learning UNESCO policy guidelines for mobile learning. France: United Nations Educational, Scientific and Cultural Organization, 2013.

[2] j. K. Sia and A. A. Adamu, "Facing the unknown: pandemic and higher education in Malaysia," Asian Educ. Dev. Stud., 2020, doi: 10.1108/AEDS-05-2020-0114.

[3] N. F. Azzahra, "Addressing distance learning barriers in Indonesia amid the Covid-19 pandemic," Jakarta Selatan, 2, 2020.

[4] R. L. Thomas and M. D. E. Fellowes, "Effectiveness of mobile apps in teaching field-based identification skills," J. Biol. Educ., no. June, 2016, doi: 10.1080/00219266.2016.1177573.

[5] A. Middleton and A. L. Nortcliffe, "Considering the Smartphone Learner: developing innovation to investigate the opportunities for students and their interest," Student Engagem. Exp. J., vol. 1, no. 1, 2012.

[6] K. Clayton and A. Murphy, "Smartphone Use as Tool for Learning," J. Media Lit. Educ., vol. 8, no. 2, pp. 99-109, 2016.

[7] S. O. Connor and T. Andrews, "Smartphone and mobile applications (apps) in clinical nursing education: A student perspective," Nurse Educ. Today, p. \#pagerange\#, 2018, doi: 10.1016/j.nedt.2018.07.013.

[8] D. Keegan, "The Future of Learning: From eLearning to mLearning," Germany, 2002. [Online]. Available: https://files.eric.ed.gov/fulltext/ED472435.pdf.

[9] Koran Tempo, "2016, Indonesia Empat Besar Pengguna Smartphone," Jakarta, 2015. [Online]. Available: https://koran.tempo.co/read/363157/2016-indonesia-empat-besarpengguna-smartphone.

[10] A. Abidah, H. Hidaayatullaah, R. Simamora, D. Fehabutar, and L. Mutakinati, "The impact of Covid-19 to Indonesian education and its relation to the philosophy of 'Merdeka Belajar ,"'Stud. Philos. Sci. Educ., vol. 1, no. 1, pp. 38-49, 2020, doi: 10.46627/sipose.v1i1.9.

[11] F. Reimers, A. Schleicher, J. Saavedra, and S. Tuominen, "Supporting the continuation of teaching and learning during the COVID-19 Pandemic," 2020. [Online]. Available: https://www.oecd.org/education/Supporting-the-continuation-ofteaching-and-learning-during-the-COVID-19-pandemic.pdf.

[12] A. Naciri, M. A. Baba, A. Achbani, and A. Kharbach, "Mobile Learning in higher education: Unavoidable alternative during COVID19," Aquademia, vol. 4, no. 1, 2020, doi: 10.29333/aquademia/8227.

[13] F. Nurlaili and B. Mulyati, "An Analysis of Students' Difficulties in Completing of the Adjustment Entries," in 1st International Multidisciplinary Conference on Education, Technology, and Engineering (IMCETE 2019), 2020, vol. 410, pp. 216-218, doi: 10.2991/assehr.k.200303.051.

[14] D. E. Sari, "Upaya Peningkatan Pemahaman Siswa Pada Kompetensi Dasar Membuat Jurnal Penyesuaian Melalui Kertas Kerja," no. November, 2015.

[15] B. Handal and J. El-khoury, "A framework for categorising mobile applications in mathematics education," in Australian Conference on Science and Mathematics Education, 2013, pp. 142-147.

[16] A. C. Camilleri and M. A. Camilleri, "Mobile Learning via Educational Apps : An Interpretative Study Mobile Learning via Educational Apps : An Interpretative Study," in 5th International Conference on Education and Training Technologies (ICETT 2019), 2019, no. May, doi: 10.1145/3337682.3337687.

[17] T. Cherner, J. Dix, and C. Lee, "Cleaning up that mess: A framework 
for classifying educational apps," Contemp. Issues Technol. Teach. Educ., vol. 14, no. 2, pp. 158-193, 2014.

[18] J. W. Creswell, Research Design: Qualitative, Quantitative, and Mixed Methods Approaches, Fourth. Los Angeles: Sage Publications, 2014

[19] J. Gikas and M. M. Grant, "Internet and higher education mobile computing devices in higher education: Student perspectives on learning with cellphones, smartphones \& social media," Internet High. Educ., vol. 19, no. 1, pp. 18-26, 2013, doi: 10.1016/j.iheduc.2013.06.002.

[20] C. Looi, P. Seow, B. Zhang, H. So, W. Chen, and L. Wong, "Leveraging mobile technology for sustainable seamless learning: A research agenda," Br. J. Educ. Technol., pp. 1-16, 2009, doi: 10.1111/j.1467-8535.2008.00912.x.

[21] S. Yang, "Exploring college students' attitudes and self-efficacy of mobile learning," Turkish Online J. Educ. Technol., vol. 11, no. 4, pp. 148-154, 2012.

[22] L. Wong, "Student Engagement with Online Resources and Its Impact on Learning Outcomes," J. Inf. Technol. Educ. Innov. Pract., vol. 12, no. 1, pp. 129-146, 2013.

[23] Y. Li and R. M. Lerner, "Interrelations of behavioral, emotional, and cognitive school engagement in high school students," J. Youth Adolesc., vol. 42, no. 1, pp. 20-32, 2013, doi: 10.1007/s10964-0129857-5.

[24] M. Wang and J. S. Eccles, "Adolescent behavioral, emotional, and cognitive engagement trajectories in school and their differential relations to educational success," J. Res. Adolesc., vol. 22, no. 1, pp. 31-39, 2011, doi: 10.1111/j.1532-7795.2011.00753.x.

[25] H. Coates, "A model of online and general campus-based student engagement," Assess. Eval. High. Educ., vol. 32, no. 2, pp. 121-141, 2007, doi: $10.1080 / 02602930600801878$.

[26] H. Coates, Student Engagement in Campus-based and Online Education: University Connections. New York: Routledge, 2006.

[27] C. Agustina and T. Wahyudi, "Aplikasi game pendidikan berbasis android untuk memperkenalkan pakaian adat Indonesia," IJSE Indones. J. Softw. Eng., vol. 1, no. 1, pp. 1-8, 2015.

[28] A. Na'im, "Pendidikan akuntansi sebagai fondasi terwujudnya akuntan profesional: Kolaborasi IAI, regulator (pemerintah) dan perguruan tinggi-Sudut pandang regulator," 2016.

[29] W. Hung, D. H. Jonassen, and R. Liu, "Problem-Based Learning," US. Army Med. Dep. J., pp. 39-47, 2010, [Online]. Available: https://www.google.com/url?sa $=\mathrm{t} \& \mathrm{rct}=\mathrm{j} \& \mathrm{q}=\& \mathrm{esrc}=\mathrm{s} \&$ source $=\mathrm{web} \& \mathrm{c}$ $\mathrm{d}=6 \&$ cad $=$ rja\&uact $=8 \&$ ved $=2$ ahUKEwiP $1 \mathrm{fq} 0 \mathrm{xcDlAhUSi3AKHf9PD}$ rwQFjAFegQICRAC\&url=https\%3A\%2F\%2Fpdfs.semanticscholar.o rg\%2F8642\%2F84970bebcd0d62bf0d31a26a1a67ba0e7883.pdf\&usg $=$ AOvVaw2XWI36fW3aEhJk8epnyIK3.

[30] S. H. Jebeile, "The spread of ICT innovation in accounting education," Int. J. Teach. Learn. High. Educ., vol. 22, no. 2, pp. 158-168, 2010.

[31] G. E. Farrelly and E. J. Hudson, "How to teach introductory accounting: Student views," J. Account. Educ., vol. 3, no. 1, pp. 47-56, 1985, doi: 10.1016/0748-5751(89)90036-5.

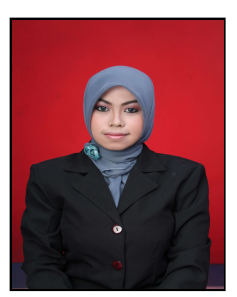

Dhany Efita Sari is studying for a doctoral degree in accounting education program at Universiti Pendidikan Sultan Idris, Malaysia. She received her bachelor's and master's degree in the economics education program in Universitas Sebelas Maret, Indonesia. She studies accounting education, education, and educational technology. Currently, she is a junior lecturer in Universitas Muhammadiyah Surakarta, Indonesia.

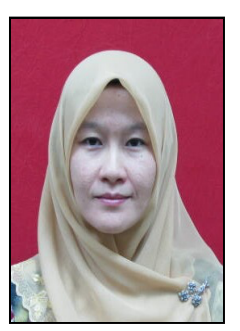

Noor Lela Ahmad is an associate professor in the Faculty of Management and Economics, Universiti Pendidikan Sultan Idris, Malaysia. She received her bachelor and master's degree at Universiti Utara Malaysia (UUM). She received her doctoral degree from Universiti Kebangsaan Malaysia (UKM). She studies accounting education accounting ethics and values, islamic ethics in accounting business education and entrepreneurship social accounting.

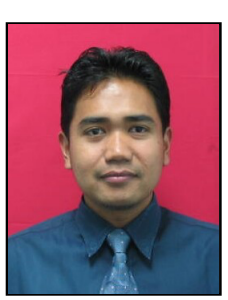

Anuar Sarun is a senior lecturer in the Faculty of Management and Economics, Universiti Pendidikan Sultan Idris, Malaysia. he received his bachelor's degree at Universiti Teknologi Mara, Malaysia. He received his master's degree at University of Wollongong, Australia. He received his doctoral's degree from Victoria University, Melbourne. He studies auditing forensic accounting, financial reporting, earnings quality, corporate governance financial planning, and accounting education.

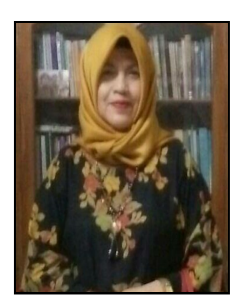

Suyatmini is a senior lecturer in the Faculty of Teacher Training and Education, Universitas Muhammadiyah Surakarta, Indonesia. She received his bachelor's degree at Universitas Negeri Yogyakarta, Indonesia. She received his master and doctoral's degree at Uniersitas Diponegoro Semarang, Indonesia. She studies accounting, general accounting, and education. 